\title{
OPTIMASI MEDIA TANAM COCOPEAT DALAM ROOT TRAINER MELALUI APLIKASI ZEOLIT DAN ASAM HUMAT PADA PEMBIBITAN KARET
}

\author{
Optimization of Root Trainer Cocopeat Planting Media Through Zeolite and Humic \\ Acid Application on Rubber Nursery
}

\author{
Charlos Togi STEVANUS* dan Andi Nur CAHYO \\ Pusat Penelitian Karet \\ Jln Raya Palembang - Pangkalan Balai KM 29 \\ Sembawa Banyuasin 30593 Sumatera Selatan \\ *Email : togie_stevanus@yahoo.co.id
}

Diterima : 12 Juli 2020 / Disetujui : 9 Agustus 2020

\begin{abstract}
Cocopeat as root trainer's planting media has low nutrition content, therefore the research on improving cocopeat in nutrient adsorption and increase nutrient uptake by plants is needed. This research aimed to determine the effect of various zeolit and humic acid dose on the growth and nutrition uptake of rubber planting material. This research was conducted in Sembawa Research Centre Nursery on April 2018 to January 2019 using IRR 112 rubber clone. This research was arranged in completely randomized design (CRD) with two factors and three replicates. The first factor was zeolit dose that consisted of four levels, namely 0 ; 7,5; 15; and 22,5 g/plant. The second level was humic acid dose, that consisted of four levels, namely $0 ; 7,5 ; 15$; and $22,5 \mathrm{~mL} / \mathrm{L}$ water. Zeolite and humic acid significantly improved lateral root and leaves biomass respectively. Furthermore, zeolite also significantly improved lateral root's $N$ and $P$ uptake as well as leaves' $N$. In addition humic acid improved leaves' $P$ and $K$ uptake as well as stem's $N$ uptake. The optimal application dose was $7.5 \mathrm{~g} /$ plant for zeolite and $7.5 \mathrm{~mL} / \mathrm{L}$ water for humic acid.
\end{abstract}

Keywords: humic acid; nutrition; root trainer; zeolite

\section{Abstrak}

Kelemahan cocopeat sebagai media tanam root trainer yaitu rendahnya kandungan nutrisi dalamnya sehingga perlu dilakukan suatu penelitian untuk meningkatkan kemampuan cocopeat dalam menahan hara, serta bagaimana meningkatkan serapan hara oleh tanaman. Salah satu pembenah tanah yang dapat digunakan adalah zeolit dan asam humat. Penelitian ini bertujuan untuk mengetahui pengaruh berbagai dosis zeolit dan asam humat terhadap pertumbuhan dan serapan hara bibit karet dalam root trainer. Penelitian ini dilaksanakan di Kebun Pembibitan Balai Penelitian Sembawa pada April 2018 sampai Januari 2019. Bibit tanaman karet yang digunakan adalah klon IRR 112. Penelitian ini disusun dalam Rancangan Acak Kelompok (RAK) dua faktor. Faktor yang pertama adalah dosis zeolit, yang terdiri atas empat aras, yaitu $0 ; 7,5 ; 15$; and 22,5 $\mathrm{g} /$ tanaman. Faktor yang kedua adalah dosis asam humat, yang terdiri atas empat aras, yaitu $0 ; 7,5 ; 15$; and $22,5 \mathrm{~mL} / \mathrm{L}$. Pengamatan dilakukan terhadap parameter pertumbuhan tanaman (tinggi tanaman, diameter batang, dan biomassa akhir), dan serapan nutrisi (N, P, dan K). Hasil pengamatan menunjukkan bahwa aplikasi zeolit berpengaruh nyata pada peningkatan biomassa akar lateral, sedangkan aplikasi asam humat berpengaruh nyata terhadap peningkatan biomassa daun. Selain itu, aplikasi zeolit mampu meningkatkan penyerapan hara $\mathrm{N}$ dan $\mathrm{P}$ pada akar lateral serta $\mathrm{N}$ pada daun. Sementara aplikasi asam humat mampu meningkatkan penyerapan hara $\mathrm{P}$ dan $\mathrm{K}$ pada daun serta $\mathrm{N}$ batang. Peningkatan serapan hara dan biomassa tanaman tersebut mencapai puncaknya pada dosis zeolit $7,5 \mathrm{~g} /$ tanaman dan dosis asam humat 7,5 mL/L air (kecuali untuk serapan $\mathrm{P}$ daun).

Kata kunci : asam humat; nutrisi; root trainer; zeolit 


\section{PENDAHULUAN}

Bibit karet yang ditumbuhkan dalam polibeg atau yang biasa disebut dengan bibit polibag memiliki kelemahan, yaitu menggulungnya akar tunggang di dasar polibag. Hal ini menyebabkan ketika bibit tanaman karet ditanam di lapangan, kedalaman akar tunggang menjadi berkurang karena akar tidak langsung tumbuh ke bawah. Selain itu, dampak lainnnya adalah kemampuan tanaman dalam menyerap air dan hara menjadi berkurang dan tanaman menjadi rentan tumbang karena terpaan angin yang kuat di lapangan (Sharma, 1987; Josiah \& Jones, 1992; Soman \& Jacob, 2013).

Untuk mengatasi kekurangan yang terdapat pada bibit karet dalam polibeg tersebut, saat ini sedang dikembangkan bibit karet dalam pot yang disebut "root trainer". Root trainer ini mempunyai ukuran yang lebih kecil dari bibit polibag sehingga diharapkan dengan digunakannya root trainer ini, bibit karet akan lebih murah, mempermudah pengangkutan dan distribusi, dan meningkatkan pertumbuhan tanaman tanpa mengurangi kelebihan kelebihan bibit karet yang terdapat pada jenis bibit karet dalam polibag (Ardika \& Herlinawati, 2014; Cahyo et al., 2016).

Menurut Soman \& Jacob (2013), media tanam yang paling ideal untuk bibit tanaman karet dalam root trainer adalah cocopeat. Cocopeat mempunyai sifat fisik yang baik, ruang pori total yang tinggi, rendah penyusutan, bobot isi yang rendah dan lambat dalam biodegradasi (Prasad, 1997; Treder, 2008) sehingga cocok untuk media tanam. Walaupun mempunyai sifat fisik yang baik, cocopeat mengandung unsur hara dengan kadar yang rendah, sehingga diperlukan pemupukan dengan dosis yang tepat dan selalu tersedia bagi tanaman untuk menjamin pertumbuhan tanaman yang optimal. Oleh karena itu perlu dilakukan penelitian untuk meningkatkan serapan dan ketersediaan unsur hara bagi tanaman. Untuk keperluan ini, dapat digunakan bahan pembenah tanah berupa zeolit untuk menekan kehilangan unsur hara dari dalam tanah dan juga asam humat untuk meningkatkan serapan hara oleh tanaman.

Zeolit dapat menekan kehilangan unsur hara karena dapat meningkatkan daya ikat air (Xiubin \& Zhanbin, 2001) dan KTK (Fudlel et al., 2019) sehingga nutrisi tanah dapat tertahan di media tanam dan tersedia bagi tanaman. Selain itu, Sepaskhah \& Yousefi (2007) dan Torma (2014) menyebutkan bahwa penambahan zeolit dapat meningkatkan status nutrisi tanah di daerah perakaran, khususnya retensi selektif dari ion $\mathrm{NH}_{4}^{+}$dan $\mathrm{K}^{+}$. Pengaruh asam humat terhadap tanaman juga telah banyak dilaporkan. Penelitian Chen et al. (2004) menunjukkan bahwa terjadi peningkatan pertumbuhan tanaman sebagai hasil dari aplikasi asam humat sebagai pembenah tanah yang meningkatkan beberapa nutrisi (zat besi dan seng). Penelitian lain menemukan bahwa asam humat dapat memengaruhi metabolisme tanaman secara langsung (Nardi et al., 2002). Tujuan penelitian ini adalah untuk mengetahui pengaruh berbagai dosis zeolit dan asam humat terhadap pertumbuhan dan serapan hara bibit karet dalam root trainer.

\section{BAHAN DAN METODE}

Penelitian ini dilaksanakan di Kebun Pembibitan Balai Penelitian Sembawa pada bulan April 2018 hingga Januari 2019. Bibit yang digunakan dalam penelitian ini adalah IRR 112. Bibit ditanam pada sebuah pot root trainer berukuran silindris dan mengecil di bagian bawah, diameter bagian atas 6-7,5 $\mathrm{cm}$, diameter bagian bawah $1,5-2 \mathrm{~cm}$, panjang $30 \mathrm{~cm}$, dan berbahan polipropilen. Kapasitas pot root trainer adalah 800 cc yang dilengkapi dengan lubang drainase dan alur vertikal. Media tanam yang digunakan untuk bibit root trainer adalah cocopeat. Analisis hara cocopeat untuk media tanam disajikan pada Tabel 1. Kriteria status hara cocopeat sebagai media tanam didasarkan penilaian kebutuhan tanaman karet (Adiwiganda et al., 1994). Berdasarkan kriteria tersebut, secara umum status hara cocopeat adalah rendah. 
Tabel1. Analisis hara cocopeat pada media tanam

Table 1. Cocopeat analysis on planting media

\begin{tabular}{cccc}
\hline Parameter & Satuan & Nilai & Status hara \\
Parameter & Unit & Value & Nutrient class \\
\hline C-Organik & $\%$ & 15,04 & Sangat tinggi \\
$\mathrm{N}$ & $\%$ & 0,74 & Sangat rendah \\
$\mathrm{P}$ & $\mathrm{ppm}$ & 310,1 & Sangat tinggi \\
$\mathrm{K}$ & $\mathrm{cmol}(+) / \mathrm{kg}$ & 1,54 & Sangat Tinggi \\
$\mathrm{Ca}$ & $\mathrm{cmol}(+) / \mathrm{kg}$ & 13,75 & Sangat rendah \\
$\mathrm{Mg}$ & $\mathrm{cmol}(+) / \mathrm{kg}$ & 14,49 & Sangat rendah \\
\hline
\end{tabular}

Rancangan percobaan yang akan digunakan adalah rancangan acak kelompok dua faktor dengan tiga ulangan. Faktor yang pertama adalah dosis zeolit, sedangkan faktor yang kedua adalah dosis asam humat. Menurut Estiaty \& Fatimah (2004) kapasitas tukar kation zeolit adalah $142,32 \mathrm{meq} / 100 \mathrm{~g}$ dan tergolong tinggi sehingga dapat mengurangi pencucian unsur hara bibit root trainer. Aplikasi zeolite dicampur dengan media tanam. Asam humat diaplikasikan dengan cara disiram pada media tanam setiap dua minggu sekali. Hasil analisis hara ditunjukkan pada Tabel 2.

Tabel2. Analisis hara asam humat pada media tanam Table2. Humic acid analysis on planting media

\begin{tabular}{ccc}
\hline Parameter & Satuan & Nilai \\
Parameter & Unit & Value \\
\hline C-Organik & $\%$ & 4,45 \\
N & $\%$ & 1,27 \\
P & ppm & 0,33 \\
K & $\%$ & 13,91 \\
$\mathrm{Ca}$ & $\%$ & 0,48 \\
$\mathrm{Mg}$ & $\%$ & 0,14 \\
$\mathrm{KTK}$ & $\mathrm{cmol}(+) / \mathrm{kg}$ & 62,16 \\
\hline
\end{tabular}

Setiap perlakuan diulang sebanyak 3 kali dengan masing-masing ulangan adalah 10 sampel tanaman. Faktor pertama (dosis zeolit) terdiri atas empat taraf, yaitu :

1. Zeolit $0 \mathrm{~g} /$ tanaman

2. Zeolit $7,5 \mathrm{~g} /$ tanaman

3. Zeolit $15 \mathrm{~g} /$ tanaman

4. Zeolit 22,5 g/tanaman

Sementara faktor kedua adalah dosis asam humat terdiri atas empat taraf, yaitu:

1. Asam humat $0 \mathrm{~mL} / \mathrm{L}$ air

2. Asam humat $7,5 \mathrm{~mL} / \mathrm{L}$ air

3. Asam humat $15 \mathrm{~mL} / \mathrm{L}$ air

4. Asam humat $22,5 \mathrm{~mL} / \mathrm{L}$ air
Bahan tanam yang akan digunakan dalam kegiatan penelitian ini adalah kecambah karet dengan stadia mentis. Untuk itu, biji yang digunakan untuk bahan tanam disemaikan terlebih dahulu dalam bedengan perkecambahan dan hanya biji yg berkecambah dalam kurun waktu maksimal 14 hari yang dipakai. Entres yang digunakan untuk okulasi adalah cabang yang berwarna hijau, yaitu payung pertama sampai kedua dari atas. Perawatan tanaman yang dilakukan adalah pemupukan setiap bulan dengan dosis $0,5 \mathrm{~g}$ menggunakan pupuk NPK majemuk (16:16:16) dan penyiangan gulma. 
Pengamatan dilakukan dalam penelitian ini antara lain:

\section{Pertumbuhan tanaman $(\mathrm{cm})$}

Pengamatan pertumbuhan tanaman terdiri atas diameter (batang bawah dan tunas hasil okulasi) dan tinggi (batang bawah dan tunas hasil okulasi). Pengamatan pertumbuhan tanaman dilakukan setiap bulan sekali. Diameter batang bawah dan tunas hasil okulasi diukur dengan menggunakan jangka sorong. Pengukuran diameter batang bawah dilakukan pada ketinggian $5 \mathrm{~cm}$ di atas permukaan tanah, sedangkan tunas hasil okulasi dilakukan pada ketinggian $5 \mathrm{~cm}$ di atas pertautan okulasi. Sementara itu, tinggi tanaman batang bawah dan hasil okulasi diukur masing-masing dari permukaan tanah dan pertautan okulasi setiap bulan sekali dengan menggunakan penggaris.

\section{Biomassa tanaman $(\mathrm{g})$}

Biomassa tanaman diukur dengan menimbang berat kering tanaman dengan mengoven tanaman pada suhu $60^{\circ} \mathrm{C}$ sampai beratnya tidak ada lagi penurunan (konstan). Waktu yang dibutuhkan agar berat biomassa konstan berkisar \pm 5 hari. Biomassa yang diukur adalah batang, daun, dan akar lateral. Pada penelitian ini, biomassa akar yang dihitung adalah akar lateral karena bibit root trainer merupakan bibit tanaman karet dengan keunggulan pada akar lateral yang lebih banyak dibandingkan dengan bibit polibeg. Selain itu, optimasi media tanam menggunakan cocopeat pada penelitian ini salah satunya adalah peningkatan akar lateral. Pengukuran akar lateral dengan cara menggunting akar lateral, kemudian dibersihkan dari kotoran media tanam. Pengukuran biomassa dilakukan pada 3 bulan setelah okulasi.
3. Serapan hara tanaman, analisa serapan hara meliputi analisa serapan N, P, dan K.

Analisis N pada tanaman dilakukan dengan menggunakan metode Kjeldahl (Mlangeni et al., 2013). Unsur hara P dan K dianalisis dengan menggunakan metode oksidasi $\mathrm{HNO}_{3}+\mathrm{HClO}_{4}$ dan diukur dengan menggunakan atomic absorption spectrophotometry (Varian Spectra 55 B) (Meller et al., 2015). Serapan unsur hara tanaman didapatkan dengan mengkalikan antara biomassa (akar, daun, atau batang) dengan hasil analisis unsur hara tanaman (Ramesh etal., 2015). Analisis data pengamatan untuk pertumbuhan, biomassa, dan serapan hara tanaman dilakukan dengan menggunakan uji Duncan's Multiple Range Test (DMRT) dengan tingkat kepercayaan 5 $\%$.

\section{HASIL DAN PEMBAHASAN}

\section{Pengaruh Optimasi Media Tanam terhadap Pertumbuhan Diameter dan Tinggi Bibit dalam Root Trainer}

Tabel 1 dan Tabel 2 menunjukkan bahwa sebelum dan sesudah okulasi, aplikasi zeolit dan asam humat tidak memberikan pengaruh nyata terhadap pertumbuhan tanaman, baik pada parameter tinggi maupun diameter batang bibit tanaman karet. Tidak adanya beda nyata pada parameter diameter batang dan tinggi tanaman tersebut disebabkan karena pertambahan diameter dan tinggi tanaman karet tersebut dipengaruhi oleh dinamika fase dormansi tunas pucuk bibit karet yang bersifat ritmik (Halle \& Martin, 1968), sehingga pengaruh aplikasi zeolit dan asam humat terhadap pertumbuhan tanaman lebih tergambar pada parameter biomassa tanaman. 
Tabel 3. Diameter batang bibit karet root trainer pada perlakuan aplikasi zeolit dan asam humat

Table 3. The effect of some level of zeolite and humic acid application on stem diameter

\begin{tabular}{|c|c|c|c|c|c|c|}
\hline \multirow[t]{2}{*}{$\begin{array}{l}\text { Perlakuan } \\
\text { Treatment }\end{array}$} & \multicolumn{3}{|c|}{$\begin{array}{c}\text { Diameter batang bawah } \\
\text { Stem diameter of root stock } \\
(\mathrm{mm})\end{array}$} & \multicolumn{3}{|c|}{$\begin{array}{c}\text { Diameter batang hasil okulasi } \\
\text { Scion diameter } \\
(\mathrm{mm})\end{array}$} \\
\hline & $1 \mathrm{BST}$ & $2 \mathrm{BST}$ & $2,5 \mathrm{BST}$ & $1 \mathrm{BSO}$ & $2 \mathrm{BSO}$ & $3 \mathrm{BSO}$ \\
\hline \multicolumn{7}{|c|}{ Dosis Zeolit (g/tan) } \\
\hline 0 & 3,20 & 4,11 & 6,17 & 4,12 & 4,47 & 4,94 \\
\hline 7,5 & 3,17 & 3,99 & 6,12 & 4,19 & 4,67 & 5,03 \\
\hline 15 & 3,17 & 3,94 & 6,15 & 4,25 & 4,44 & 4,74 \\
\hline 22,5 & 3,18 & 4,03 & 6,09 & 4,02 & 4,23 & 4,85 \\
\hline \multicolumn{7}{|c|}{$\begin{array}{l}\text { Dosis asam humat } \\
\text { Humic acid dosage } \\
\text { (mL/L) }\end{array}$} \\
\hline 0 & 3,24 & 4,08 & 4,08 & 4,15 & 4,25 & 4,89 \\
\hline 7,5 & 3,19 & 4,05 & 4,05 & 4,09 & 4,36 & 4,87 \\
\hline 15 & 3,16 & 4,00 & 4,00 & 4,06 & 4,33 & 4,82 \\
\hline 22,5 & 3,13 & 3,93 & 3,93 & 4,23 & 4,45 & 4,99 \\
\hline
\end{tabular}

Keterangan : Angka yang diikuti huruf yang berbeda menunjukkan adanya beda nyata pada uji Duncan Multiple Range Test pada tingkat ketidak percayaan $5 \%$

Remarks : Means with different alphabets in columns indicate significant difference between treatments by Duncan Multiple Range Test at $P \leq 0.05$.

BST $=$ Bulan setelah tanam (months after planting)

$\mathrm{BSO}=$ Bulan setelah okulasi (months after budding)

Tabel4. Tinggi bibit karet dalam root trainer pada perlakuan aplikasi zeolite dan asam humat Table 4. The effect of some level of zeolite and humic acid application on plant height

\begin{tabular}{|c|c|c|c|c|c|c|}
\hline \multirow[t]{2}{*}{$\begin{array}{l}\text { Perlakuan } \\
\text { Treatment }\end{array}$} & \multicolumn{3}{|c|}{$\begin{array}{l}\text { Tinggi tanaman } \\
\text { Plant height } \\
(\mathrm{cm})\end{array}$} & \multicolumn{3}{|c|}{$\begin{array}{l}\text { Tinggi tanaman } \\
\text { Plant height } \\
(\mathrm{cm})\end{array}$} \\
\hline & $1 \mathrm{BST}$ & $2 \mathrm{BST}$ & $3 \mathrm{BST}$ & $1 \mathrm{BSO}$ & $2 \mathrm{BSO}$ & $3 \mathrm{BSO}$ \\
\hline \multicolumn{7}{|c|}{ Dosis Zeolit (g/tan) } \\
\hline \multicolumn{7}{|c|}{ Zeolite dosage (g/tree) } \\
\hline $\mathrm{AO}$ & 21,55 & 34,18 & 47,51 & 13,42 & 16,37 & 17,98 \\
\hline A1 & 21,55 & 35,54 & 50,53 & 12,66 & 16,93 & 19,22 \\
\hline $\mathrm{A} 2$ & 21,77 & 36,45 & 50,12 & 14,25 & 15,97 & 17,98 \\
\hline A3 & 19,92 & 35,53 & 50,89 & 14,12 & 15,73 & 17,42 \\
\hline \multirow{2}{*}{\multicolumn{7}{|c|}{$\begin{array}{c}\text { Dosis asam humat } \\
\text { Humic acid dosage } \\
(\mathrm{mL} / \mathrm{L})\end{array}$}} \\
\hline & & & & & & \\
\hline ZO & 21,23 & 34,51 & 49,83 & 12,95 & 15,22 & 17,09 \\
\hline$Z 1$ & 21,00 & 36,73 & 50,50 & 13,79 & 16,82 & 19,17 \\
\hline $\mathrm{Z2}$ & 21,50 & 36,16 & 49,64 & 12,94 & 16,76 & 18,83 \\
\hline Z3 & 21,00 & 34,97 & 49,35 & 14,33 & 16,02 & 18,32 \\
\hline
\end{tabular}

Keterangan : Angka yang diikuti huruf yang berbeda menunjukkan adanya beda nyata pada uji Duncan Multiple Range Test pada tingkat ketidak percayaan $5 \%$

Remarks : Means with different alphabets in column indicate significant difference between treatments by Duncan Multiple Range Test at $P \leq 0.05$.

$\mathrm{BST}=$ Bulan setelah tanam (months after planting)

$\mathrm{BSO}=$ Bulan setelah okulasi (months after budding) 


\section{Pengaruh Optimasi Media Tanam terhadap Biomassa dan Penyerapan Unsur Hara pada Bibit Root Trainer}

Penggunaan zeolite pada root trainer mampu meningkatkan biomassa akar lateral root trainer, sedangkan aplikasi asam humat mampu meningkatkan biomassa daun. Peningkatan biomassa akar lateral salah satunya disebabkan oleh meningkatnya penyerapan unsur hara $\mathrm{N}$ pada akar dan daun melalui aplikasi zeolite (Tabel 4 dan Tabel 5). Zeolit merupakan mineral yang efektif dalam mengendalikan pelepasan unsur hara (Leggo, 2000) terutama $\mathrm{N}$ yang mudah hilang karena pencucian. Hasil penelitian Razaq et al. (2017) menunjukkan bahwa unsur N pada tanaman dapat meningkatkan panjang dan morfologi akar serta kandungan klorofil pada tanaman. Seperti pada aplikasi zeolite, peningkatan biomassa daun pada bibit root trainer terjadi karena adanya peningkatan penyerapan unsur hara yaitu $\mathrm{P}$ dan $\mathrm{K}$ pada daun melalui aplikasi asam humat (Tabel 5 dan Tabel 6). Pasokan P yang tinggi pada tanaman menurut penelitian Kim \& $\mathrm{Li}$, (2016) memiliki efek nyata dalam peningkatan jumlah daun dan permukaan luas daun, yang selanjutnya menyebabkan peningkatan biomassa daun.

Tabe15. Pengaruh aplikasi zeolite dan asam humat terhadap biomassa tanaman

Table 5. The effect of some level of zeolite and humic acid application on plant biomass

\begin{tabular}{|c|c|c|c|c|}
\hline \multirow{2}{*}{$\begin{array}{l}\text { Perlakuan } \\
\text { Treatment }\end{array}$} & \multicolumn{4}{|c|}{$\begin{array}{c}\text { Biomassa } \\
\text { Biomass } \\
(\mathrm{g})\end{array}$} \\
\hline & $\begin{array}{l}\text { Akar lateral } \\
\text { Lateral root }\end{array}$ & $\begin{array}{c}\text { Batang } \\
\text { Bark }\end{array}$ & $\begin{array}{l}\text { Daun } \\
\text { Leaf }\end{array}$ & Total \\
\hline \multicolumn{5}{|c|}{ Dosis Zeolit (g/tan) } \\
\hline \multicolumn{5}{|c|}{ Zeolite dosage ( $\mathrm{g} /$ tree) } \\
\hline 0 & $1,03 \quad b$ & 0,93 & 2,73 & 4,69 \\
\hline 7,5 & 1,78 a & 0,91 & 2,35 & 5,04 \\
\hline 15 & $1,21 \quad a b$ & 0,95 & 2,56 & 4,72 \\
\hline 22,5 & $1,38 \mathrm{ab}$ & 0,81 & 2,68 & 4,87 \\
\hline \multicolumn{5}{|c|}{$\begin{array}{c}\text { Dosis asam humat } \\
\text { Humic acid dosage } \\
(\mathrm{mL} / \mathrm{L})\end{array}$} \\
\hline 0 & 1,40 & 0,78 & 2,02 & 4,20 \\
\hline 7,5 & 1,33 & 0,95 & 3,29 & 5,57 \\
\hline 15 & 1,23 & 0,87 & 2,43 & 4,53 \\
\hline 22,5 & 1,39 & 0,99 & 2,63 & 5,01 \\
\hline
\end{tabular}

Keterangan : Angka yang diikuti huruf yang berbeda menunjukkan adanya beda nyata pada uji Duncan Multiple Range Test pada tingkat ketidak percayaan $5 \%$

Remarks : Means with different alphabets in column indicate significant difference between treatments by Duncan Multiple Range Test at $P \leq 0.05$.

Peningkatan serapan hara (Ahmed et al., 2010; Ozbahce et al., 2015) K pada Tabel 6 tersebut sejalan dengan hasil penelitian terdahulu yang menemukan bahwa aplikasi asam humat dapat meningkatkan kandungan unsur $\mathrm{N}$ dan $\mathrm{K}$ pada batang (Cahyo et al. 2014) serta serapan N, P, dan K pada daun (Tehranifar \& Ameri, 2014). Seperti halnya pada penelitian Cahyo et al. (2014) aplikasi asam humat pada penelitian ini juga tidak memberikan pengaruh terhadap serapan hara ( $\mathrm{N}, \mathrm{P}$, dan $\mathrm{K})$ akar. Hal ini mengindikasikan bahwa asam humat tidak memengaruhi peningkatan status hara tanaman secara langsung pada organ yang pertama kali menyerap asam humat tersebut, namun melalui peningkatan metabolisme seluler seperti halnya mekanisme auksin bekerja. Merlo et al. (1991) dan Trevisan et al. (2011) berpendapat bahwa asam humat dapat memengaruhi proses fisiologis tanaman melalui mekanisme seperti hormon auksin. 
Tabe16. Pengaruh perlakuan zeolit dan asam humat terhadap penyerapan $\mathrm{N}$ tanaman Table 6. The effect of some level of zeolite and humic acid application on plant's $N$ uptake

\begin{tabular}{|c|c|c|c|c|}
\hline \multirow{2}{*}{$\begin{array}{l}\text { Perlakuan } \\
\text { Treatment }\end{array}$} & \multicolumn{4}{|c|}{$\begin{array}{c}\text { Penyerapan } \mathrm{N} \text { tanaman } \\
N \text { Uptake } \\
(\mathrm{g})\end{array}$} \\
\hline & $\begin{array}{l}\text { Akar lateral } \\
\text { Lateral root }\end{array}$ & $\begin{array}{c}\text { Batang } \\
\text { Bark }\end{array}$ & $\begin{array}{l}\text { Daun } \\
\text { Leaf }\end{array}$ & Total \\
\hline \multicolumn{5}{|c|}{$\begin{array}{c}\text { Dosis Zeolit (g/tan) } \\
\text { Zeolite dosage (g/tree) }\end{array}$} \\
\hline 0 & $0,58 \quad a b$ & 0,43 & $2,02 \quad b$ & 3,03 \\
\hline 7,5 & 0,66 & 0,54 & 3,29 a & 4,49 \\
\hline 15 & $0,42 \quad a b$ & 0,46 & $2,43 \mathrm{ab}$ & 3,31 \\
\hline 22,5 & 0,40 & 0,48 & $2,63 \mathrm{ab}$ & 3,51 \\
\hline \multicolumn{5}{|c|}{$\begin{array}{l}\text { Dosis asam humat } \\
\text { Humic acid dosage } \\
\text { (mL/L) }\end{array}$} \\
\hline 0 & 0,59 & $0,28 \quad b$ & 2,73 & 3,60 \\
\hline 7,5 & 0,51 & 0,57 & 2,34 & 3,42 \\
\hline 15 & 0,58 & 0,56 a & 2,56 & 3,70 \\
\hline 22,5 & 0,42 & 0,50 & 2,68 & 3,60 \\
\hline
\end{tabular}

Keterangan : Angka yang diikuti huruf yang berbeda menunjukkan adanya beda nyata pada uji Duncan Multiple Range Test pada tingkat ketidak percayaan $5 \%$

Remarks : Means with different alphabets in column indicate significant difference between treatments by Duncan Multiple Range Test at $P \leq 0.05$.

Selain itu, asam humat dapat meningkatkan serapan anion dan kation, enzim untuk sintesa protein dan metabolisme nitrat (Dell'Agnola \& Nardi,1987; Muscolo et al., 1999). Selain itu Valdrighi et al. (1996) juga menyebutkan bahwa asam humat dapat meningkatkan serapan nutrisi dengan meningkatkan permeabilitas membran sel akar. Selain itu, auksin dapat meningkatkan pertukaran proton, kapasitas membran, dan serapan K (Gardner et al., 1985). Oleh karena itu aplikasi asam humat dapat meningkatkan serapan $\mathrm{N}$ dan $\mathrm{K}$ pada organ tanaman. Hal ini juga berarti bahwa aplikasi asam humat tidak harus diberikan langsung ke bagian akar tanaman, namun dapat juga lewat penyemprotan pada daun (foliar application) karena auksin ditranslokasikan secara polar basipetal (dari pucuk tunas ke arah bagian akar).

Pengaruh aplikasi asam humat pada peningkatan serapan $\mathrm{N}$ pada batang dan $\mathrm{K}$ pada daun yang nyata tersebut (Tabel 4 dan 6 berturut-turut) mempunyai pola peningkatan pada dosis $7,5 \mathrm{~mL} / \mathrm{L}$ kemudian menurun pada dosis yang lebih tinggi. Hal ini menunjukkan bahwa dosis aplikasi asam humat $7,5 \mathrm{~mL} / \mathrm{L}$ merupakan dosis yang paling optimal untuk aplikasi asam humat pada media tanam.
Hal ini sejalan dengan hasil penelitan yang dilakukan oleh Tattini et al. (1991) bahwa serapan $\mathrm{N}$ oleh tanaman zaitun meningkat pada konsentrasi asam humat 30-120 mg/pot, namun kemudian menurun seiring dengan peningkatan dosis asam humat. Hal ini berarti bahwa asam humat dapat secara optimal meningkatkan serapan hara tanaman pada rentang dosis tertentu.

Seperti halnya pada pengaruh aplikasi asam humat, aplikasi zeolit pada bibit tanaman karet juga menunjukkan peningkatan serapan yang nyata pada $\mathrm{N}$ dan $\mathrm{P}$ pada akar serta $\mathrm{N}$ pada daun yang menunjukkan pola penurunan serapan $\mathrm{N}$ dan $P$ pada dosis di atas $7,5 \mathrm{~g} /$ tanaman. Ada penurunan serapan $\mathrm{N}$ dan $\mathrm{P}$ pada dosis di atas $7,5 \mathrm{~g} /$ tanaman ini dimungkinkan terjadi karena adanya dilution effect (Jarrell \& Beverly, 1981). Penurunan serapan hara pada dosis zeolit di atas dosis optimal ini juga terjadi pada beberapa penelitian mengenai pengaruh dosis aplikasi zeolit terhadap serapan hara tanaman (Ahmed et al., 2010; Ozbahce et al., 2015). Hal ini menunjukkan bahwa sebaiknya zeolit diberikan pada dosis $7,5 \mathrm{~g} /$ tanaman untuk bibit root trainer. 
Tabe17. Pengaruh perlakuan zeolit dan asam humat terhadap penyerapan $\mathrm{P}$ tanaman Table 7. The effect of some level of zeolite and humic acid application on plant's P uptake

\begin{tabular}{|c|c|c|c|c|}
\hline \multirow{2}{*}{$\begin{array}{l}\text { Perlakuan } \\
\text { Treatment }\end{array}$} & \multicolumn{4}{|c|}{$\begin{array}{c}\text { Penyerapan P tanaman } \\
P \text { Uptake } \\
\text { (g) }\end{array}$} \\
\hline & $\begin{array}{l}\text { Akar } \\
\text { Root }\end{array}$ & $\begin{array}{c}\text { Batang } \\
\text { Bark }\end{array}$ & $\begin{array}{l}\text { Daun } \\
\text { Leaf }\end{array}$ & Total \\
\hline \multicolumn{5}{|c|}{ Dosis Zeolit (g/tan) } \\
\hline 0 & $0,21 \quad b$ & 0,33 & 0,68 & 1,22 \\
\hline 7,5 & 0,34 a & 0,29 & 0,56 & 1,19 \\
\hline 15 & $0,26 \mathrm{ab}$ & 0,30 & 0,51 & 1,07 \\
\hline 22,5 & $0,32 \quad a$ & 0,30 & 0,59 & 1,21 \\
\hline \multicolumn{5}{|c|}{$\begin{array}{l}\text { Dosis asam humat } \\
\text { Humic acid dosage } \\
(\mathrm{mL} / \mathrm{L})\end{array}$} \\
\hline 0 & 0,35 & 0,24 & 0,41 & 1,00 \\
\hline 7,5 & 0,27 & 0,35 & $0,68 \quad a b$ & 1,30 \\
\hline 15 & 0,22 & 0,29 & $0,55 a b$ & 1,06 \\
\hline 22,5 & 0,29 & 0,34 & $0,71 \quad a$ & 1,34 \\
\hline \multicolumn{5}{|c|}{$\begin{array}{l}\text { Keterangan : Angka yang diikuti huruf yang berbeda menunjukkan adanya beda nyata pada uji } D \\
\text { Multiple Range Test pada tingkat ketidak percayaan } 5 \% \\
\text { Remarks } \quad \text { Means with different alphabets in column indicate significant difference between } \\
\text { treatments by Duncan Multiple Range Test at } P \leq 0.05 .\end{array}$} \\
\hline
\end{tabular}

Tabel8. Pengaruh perlakuan zeolite dan asam humat terhadap penyerapan $\mathrm{K}$ tanaman Table 8. The effect of some level of zeolite and humic acid application on plant's $K$ uptake

\begin{tabular}{|c|c|c|c|c|c|}
\hline \multirow{2}{*}{$\begin{array}{l}\text { Perlakuan } \\
\text { Treatment }\end{array}$} & \multicolumn{5}{|c|}{$\begin{array}{c}\text { Penyerapan K tanaman } \\
\text { K Uptake } \\
(\mathrm{g})\end{array}$} \\
\hline & $\begin{array}{l}\text { Akar } \\
\text { Root }\end{array}$ & $\begin{array}{c}\text { Batang } \\
\text { Bark }\end{array}$ & $\begin{array}{l}\text { Daun } \\
\text { Leaf }\end{array}$ & & Total \\
\hline \multicolumn{6}{|c|}{ Dosis Zeolit (g/tan) } \\
\hline \multicolumn{6}{|c|}{ Zeolite dosage (g/tree) } \\
\hline 0 & 1,38 & 1,62 & 3,41 & & 6,41 \\
\hline 7,5 & 1,04 & 1,38 & 2,86 & & 5,28 \\
\hline 15 & 1,20 & 1,70 & 2,99 & & 5,89 \\
\hline 22,5 & 1,31 & 1,51 & 3,29 & & 6,11 \\
\hline \multicolumn{6}{|c|}{$\begin{array}{l}\text { Dosis asam humat } \\
\text { Humic acid dosage } \\
\text { (mL/L) }\end{array}$} \\
\hline 0 & 1,38 & 1,31 & 2,46 & $\mathrm{~b}$ & 5,15 \\
\hline 7,5 & 1,04 & 1,59 & 3,96 & a & 6,59 \\
\hline 15 & 1,20 & 1,76 & 3,04 & $a b$ & 6,00 \\
\hline 22,5 & 1,31 & 1,55 & 3,26 & $a b$ & 6,12 \\
\hline
\end{tabular}

Keterangan : Angka yang diikuti huruf yang berbeda menunjukkan adanya beda nyata pada uji Duncan Multiple Range Test pada tingkat ketidak percayaan $5 \%$

Remarks : Means with different alphabets in column indicate significant difference between treatments by Duncan Multiple Range Test at $P \leq 0.05$. 


\section{KESIMPULAN}

Aplikasi zeolit dan asam humat pada media tanam root trainer dapat meningkatkan penyerapan unsur hara pada tanaman. Dengan meningkatnya penyerapan unsur hara tersebut, kebutuhan nutrisi tanaman menjadi tercukupi sehingga biomassa tanaman juga meningkat. Peningkatan serapan hara dan biomassa tanaman tersebut mencapai puncaknya pada dosis zeolit 7,5 g/tanaman dan dosis asam humat 7,5 mL/L air (kecuali untuk serapan $\mathrm{P}$ daun). Di atas dosis tersebut, serapan hara mulai menurun. Hal ini menunjukkan bahwa dosis optimal aplikasi zeolit 7,5 g/tanaman, dan dosis optimal aplikasi asam humat 7,5 mL/L air.

\section{DAFTAR PUSTAKA}

Adiwiganda, Y.T., Hardjono, Manurung, A., Sihotang, U.T.B., Darmandono, Sudiharto, Goenadi, D.H., \& Sihombing, H. (1994). Teknik penyusunan rekomendasi pemupukan tanaman karet. Forum Komunikasi Karet. Medan, Indonesia: Pusat Penelitian Karet.

Ahmed, O.H., Sumalatha, G., \& Muhamad, A.M.N. (2010). Use of zeolite in maize (Zea mays) cultivation on nitrogen, potassium and phosphorus uptake and use efficiency. International Journal of the Physical Sciences, 5(15), 2393-2401.

Ardika, R., \& Herlinawati, E. (2014). Alternatif penyediaan bahan tanam karet dengan sistem root trainer. Warta Perkaretan, 33(2), 73-78. https: / / doi.org/ 10.22302/ppk.wp.v $33 \mathrm{i} 2.52$

Cahyo, A. N., Ardika R., Saputra, J., \& Wijaya T. (2014). Acceleration on the growth of rubber planting materials by using foliar application of humic acid. AGRIVITA， 36(2), 112 - 119. http:/ / doi.org/ 10.17503/agrivita.v3 $6 i 2.397$
Cahyo, A. N., Saputra, J., Stevanus, C.T., \& Sahuri. (2016). Penggunaan root trainer untuk meningkatkan pertumbuhan bibit karet. Jurnal Penelitian dan Pengembangan Pertanian, 35(1), $17-24$. https://doi.org/10.21082/jp3.v35n 1.2016.p17-24

Chen, Y., Clapp, C.E., \& Magen, H. (2004). Mechanisms of plant growth stimulation by humic substances: The role of organo-iron complexes. Soil Science and Plant Nutrition, 50(7), $\begin{array}{lllllllll}1 & 0 & 8 & 9 & - & 1 & 0 & 9 & 5\end{array}$. https://doi.org/10.1080/00380768 .2004.10408579

Dell'Agnola, G., \& Nardi, S. (1987). Hormone like effect and enhanced nitrate uptake induced by depolycondensed humic fractions obtained from Allolobophora rosea and A. caliginosa faeces. Biology and Fertility of Soils, $4 \quad, \quad \begin{array}{lll}4 & 1 & 5\end{array}$ 118.https: / / doi.org/ 10.1007 / BF00 256983

Estiaty, L.M., \& Fatimah, D. (2004). Zeolit alam Cikancra Tasikmalaya: media penyimpan ion amonium dari pupuk amonium sulfat. Jurnal Zeolit Indonesia, 3(2), 55-61.

Fudlel, A.Y., Minardi, S., Hartati, S., \& Syamsiyah, J. (2019). Studying the residual effect of zeolite and manure on alfisols cation exchange capacity and green bean yield. Journal of Soil Science and Agroclimatology, 16(2), $\begin{array}{lllllll}1 & 8 & 1 & - & 1 & 9 & 0\end{array}$. https: / /doi.org/ 10.20961/stjssa.v1 6i2.30190

Gardner, F.P., Pearce, R.B., \& Mitchell, R.L. (1985). Physiology of Crop Plants. Iowa, USA: Iowa State University Press. 
Hallé, F., \& Martin, R. (1969). Étude de La croissance rythmique chez l'Hevea (Hévéa brasiliensis Müll. Arg. euphorbiachées crotonoidées). Adansonia-Ser. 2, 8(4), 1 - 25.

Jarrell, W.M., \& Beverly, R.B. (1981). The dilution effect in plant nutrition studies. Advances in Agronomy, 34, $\begin{array}{lllllll}1 & 9 & 7 & - & 2 & 2 & 4\end{array}$. https://doi.org/10.1016/S00652113(08)60887-1

Josiah, S.J., \& Jones, N. (1992). Root Trainers in Seedling Production System For Tropical Forestry And Agro-Forestry. Wahington, USA: The World Bank.

Kim, H.J., \& Li, X. (2016). Effects of phosphorus on shoot and root growth, partitioning, and phosphorus utilization efficiency in lantana. Hort Science, 51 (8), $\begin{array}{lllllllll}1 & 0 & 0 & 1 & - & 1 & 0 & 0 & 9\end{array}$. https://doi.org/ 10.21273/HORTSC I.51.8.1001

Leggo, P.J. (2000). An investigation of plant growth in an organo-zeolitic substrate and its ecological significance. Plant and Soil, 219, $\begin{array}{lllllll}1 & 3 & 5 & - & 1 & 4 & 6\end{array}$. https://doi.org/10.1023/A:100474 4612234

Meller, E., Niedźwiecki, E., Rogalska, P., Jarnuszewski, G., \& Wilczyński, D. (2015). Fertiliser value and trace element content of composts produced from different wastes. Journal of Ecological Engineering, $16, \quad 154 \quad 4 \quad \begin{array}{llll}1 & 6 & 0\end{array}$. https://doi.org/10.12911/2299899 3/59365
Merlo, L., Ghisi, R., Rascio, N., \& Passera, C. (1991). Effects of humic substances on carbohydrate metabolism of maize leaves. Canadian Journal of Plant Science, 71 (2), 419-425. https://doi.org/10.4141/cjps91058

Muscolo, A., Bovalo, F., Gionfriddo, F., \& Nardi, S. (1999). Earthworm humic matter produces auxin-like effects on Daucus carota cell growth and nitrate metabolism. Soil Biology and Biochemistry, 31, 1303-1311. https://doi.org/10.1016/S00380717(99)00049-8

Mlangeni, A.N.J.T., Sajidu, S., \& Chiotha, S.S. (2013). Total Kjeldahl-N, Nitrate$\mathrm{N}, \mathrm{C} / \mathrm{N}$ ratio and $\mathrm{pH}$ improvements in chimato composts using Tithonia diversifolia. Journal of Agricultural Scie nce, 5 ( 10 ), 1 - 9 . https://doi.org/10.5539/jas.v5n10 p1

Nardi, S., Pizzeghello, D., Muscolo, A., \& Vianello, A. (2002). Physiological effects of humic substances on higher plants. Soil Biology and Biochemistry, 34(11), 1527-1536. https://doi.org/10.1016/S00380717(02)00174-8

Ozbahce, A., Tari, A.F., Gönülal, E., Simsekli, N., \& Padem, H. (2015). The effect of zeolite applications on yield components and nutrient uptake of common bean under water stress. Archives of Agronomy and Soil Science, 61(5), 615-626. https://doi.org/10.1080/03650340 .2014 .946021 
Prasad, M. (1997). Pysical, chemical, and biological properties of coir dust. Acta Horticulturae, 450, 21-29. https://doi.org/10.17660/ActaHort ic. 1997.450 .1

Ramesh, V., George, J., Jyothi, J.S., \& Shibli, S.M.A. (2015). Effect of zeolites on soil quality, plant growth and nutrient uptake efficiency in sweet potato (Ipomoea batatas L.). Journal of Root Crops, 41(1), 25-31.

Razaq, M., Zhang, P., Shen, H., \& Salahuddin. (2017). Influence of nitrogen and phosphorous on the growth and root morphology of Acer mono. PLOS ONE, 12(2), 1-13. https://doi.org/10.1371/journal.po ne.0171321

Sepaskhah, A.R., \& Yousefi, F. (2007). Effects of zeolite application on nitrate and ammonium retention of a loamy soil under saturated conditions. Soil Research, 45(5), 368-373. https://doi.org/10.1071/SR06069

Sharma, R.D. (1987). Some observations on coiling of roots in nursery raised plants. Journal of Tropical Forestry, 3(3), 207-212.

Soman, T.A., \& Jacob, J. (2013). Root Trainer Planting Technique for Hevea. Bogor, Indonesia: Pusat Penelitian Karet Indonesia.
Tattini, M., Bertoni, P., Landi, A., \& Traversim, M.L. (1991). Effect of humic acids on growth and biomass partitioning of container grown olive plants. Acta Horticulturae, 294, 75-80. https://doi.org/10.17660/ActaHorti c. 1991.294 .7

Tehranifar, A., \& Ameri, A. (2014). Effect of humic acid on nutrient uptake and physiological characteristics of fragaria Ananassa "Camarosa." Acta Horticulturae, 1049, 391-394. https://doi.org/10.17660/ActaHort ic. 2014.1049 .54

Torma, S., Vilcek, J., Adamisin, P., Huttmanova, E., \& Hronec, O. (2014). Influence of natural zeolite on nitrogen dynamics in soil. Turkish Journal of Agriculture and Forestry,

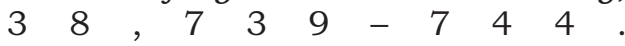
https://doi.org/10.3906/tar-1311-13

Treder, J. (2008). The effects of cocopeat and fertilization on the growth and flowering of oriental lily 'star gazer.' Journal of Fruit and Ornamental Plant Research, 16, 361-370.

Trevisan, S., Botton, A., Vaccaro, S., Vezzaro, A., Quaggiotti, S., \& Nardi, S. (2011). Humic substances affect Arabidopsis physiology by altering the expression of genes involved in primary metabolism, growth and development. Environmental and Experimental Botany, 74, 4555.https://doi.org/10.1016/j.envex pbot.2011.04.017 
Valdrighi, M.M., Pera, A., Agnolucci, M., Frassinetti, S., Lunardi, D., \& Vallini, G. (1996). Effects of compost-derived humic acids on vegetable biomass production and microbial growth within a plant (Cichorium intybus)soil system: a comparative study. Agriculture, Ecosystems and Environment, 58(2-3), 133-144. https://doi.org/10.1016/01678809(96)01031-6
Xiubin, H., \& Zhanbin, H. (2001). Zeolite application for enhancing water infiltration and retention in loess soil. Resources, Conservation and Recycling, 34(1), 45-52. https:// doi.org/10.1016/S09213449(01)00094-5 